\title{
Dampak E-Learning terhadap Anggaran Pelatihan Kementerian Keuangan
}

Jurnal Akuntansi Terapan Indonesia Vol 4 No 1 Hal 14-32 March 2021

\section{Affiliation:}

Universitas Indonesia, Indonesia

*Correspondence:

ditarakhmadina@gmail.com

This Article is Available in: https://journal.umy.ac.id/index. php/jati/article/view/10343

\section{DOI:}

https://doi.org/10.18196/jati.v4i1.103 43

\section{Citation:}

Rakhmadina, D., \& Setyaningrum, D. (2021). Dampak E-Learning terhadap Anggaran Pelatihan Kementerian Keuangan. Jati: Jurnal Akuntansi Terapan Indonesia, 4(1), 14-32.

\section{Article History}

Received:

27 November 2020

Reviewed:

12 December 2020

Revised:

07 January 2021

Accepted:

09 February 2021

Topic Article:

Public Sector Accounting
Dita Rakhmadina*1, Dyah Setyaningrum²

\begin{abstract}
:
This study aimed to analyze the impact of e-learning on training budgets, compare the standard costs of traditional training and e-learning, and formulate standard output costs of e-learning. This study was conducted to provide recommendations for improving budget efficiency in government organizations. This research uses a qualitative method with a case study approach by exploring phenomena in the government budget due to e-learning implementation. Data collection techniques were interviews, observation, and documentation. The results showed that e-learning implementation significantly saves the training budget and increases the number of training participants. However, the cost standard is less optimal because they do not cover all the costs needed to deliver e-learning. The standard costs should be differentiated for each type of e-learning. Also, the current organizational structure needs to be changed to achieve maximum efficiency in e-learning implementation.
\end{abstract}

Keywords: Budget, Efficiency, E-Learning, New Public Management

\section{Abstrak:}

Penelitian ini bertujuan untuk menganalisis dampak e-learning terhadap anggaran pelatihan, perbandingan standar biaya keluaran pelatihan klasikal dan e-learning, dan penyusunan standar biaya keluaran sesuai dengan komponen pembentuk biaya yang diperlukan untuk menyelenggarakan elearning. Penelitian ini diharapkan dapat memberikan rekomendasi dalam rangka meningkatkan efisiensi anggaran pada organisasi pemerintah penyelenggara pendidikan dan pelatihan. Penelitian ini menggunakan metode kualitatif dengan pendekatan studi kasus dengan menggali fenomena yang terjadi pada anggaran suatu instansi pemerintah sebagai akibat dari penyelenggaraan e-learning. Pengumpulan data dilakukan dengan teknik wawancara, observasi, dan telaah dokumen. Hasil penelitian menunjukkan bahwa penyelenggaraan pelatihan e-learning secara signifikan dapat menghemat anggaran pelatihan dan meningkatkan jumlah peserta yang dapat dilatih. Namun, standar biaya yang disusun saat ini belum optimal karena belum mencerminkan seluruh biaya yang diperlukan untuk menyelenggarakan e-learning. Standar biaya yang disusun sebaiknya dibedakan sesuai jenis pelatihan e-learning. Selain itu, untuk meningkatkan efisiensi anggaran atas pelaksanaan e-learning diperlukan penyesuaian kebutuhan kompetensi SDM dan struktur organisasi yang ada saat ini yang lebih sesuai dengan proses bisnis pelatihan e-learning.

Kata Kunci: Anggaran, Standar Biaya, Efisiensi, E-Learning

\section{PENDAHULUAN}

Pengembangan sumber daya manusia berupa permbelajaran berkelanjutan (continuous learning) dan pengembangan keterampilan merupakan factor yang penting untuk kemajuan organisasi (Kraiger et al., 2014). Dalam kehidupan berbangsa dan bernegara, pemerintah Indonesia 
sesuai dengan amanat Pasal 31 ayat 4 Undang Undang Dasar Tahun 1945 harus memprioritaskan anggaran pendidikan sekurang-kurangnya dua puluh persen dari Anggaran Pendapatan dan Belanja Negara (APBN) serta Anggaran Pendapatan Belanja Daerah (APBD). Oleh sebab itu, dalam kondisi pandemi sekalipun, kegiatan pendidikan sepatutnya terus dilaksanakan.

COVID-19 diumumkan oleh World Health Organization (WHO) sebagai pandemi global sejak tanggal 11 Maret 2020 (Utomo, 2020; Wicaksono, 2020). Kebijakan lockdown maupun social distancing yang diberlakukan untuk menekan penyebaran virus kemudian berpengaruh pada gaya hidup masyarakat, tidak terkecuali kegiatan belajar mengajar. Selama pandemi berlangsung, online learning telah dilakukan hampir di seluruh dunia (Goldschmidt, 2020; Radha et al., 2020). Peserta didik melakukan kegiatan belajar dari rumah dengan menggunakan teknologi. COVID-19 mendorong terjadinya transformasi digital di sektor pendidikan (Bogdandy et al., 2020; livari et al., 2020). Kebutuhan akan elearning menjadi lebih besar sejak terjadinya coronavirus disease (COVID-19).

Konsep e-learning mengacu pada pembelajaran melalui sarana elektronik dan menyediakan pembelajaran jarak jauh interaktif yang menggunakan sistem web sebagai cara untuk mengakses informasi yang tersedia tanpa dibatasi oleh ruang dan waktu (Aparicio, Bacao, dan Oliveira, 2016). E-learning merupakan penyampaian informasi menggunakan media teknologi komunikasi dalam pendidikan dan pelatihan (Sun, Tsai, Finger, Chen, dan Yeh, 2008).

Penelitian tentang e-learning telah banyak dilakukan, namun sebagian besar penelitian tersebut melihat dari sisi e-learning sebagai metode pembelajaran. Selim (2007) menguji tentang faktor penentu keberhasilan penyelenggaraan e-learning dengan menggunakan model confirmatory factor. Zhang, Zhao, Zhou, dan Nunamaker (2004) meneliti tentang penggunaan e-learning untuk menggantikan pelatihan tradisional bagi pegawai di tempat kerja sebagai lifetime learning. Deming, Goldin, Katz, dan Yuchtman (2015) membahas tentang bagaimana online learning dapat digunakan oleh perguruan tinggi dengan membebankan biaya yang lebih rendah. Penelitian yang dilakukan oleh Deming et al. (2015) melakukan tabulasi atas data biaya perkuliahan perguruan tinggi dan hasil tabulasi menunjukkan bahwa perguruan tinggi yang melaksanakan pembelajaran online lebih banyak membebankan biaya perkuliahan yang lebih rendah. Sementara, penelitian ini akan menjawab bagaimana dampak pelatihan e-learning terhadap anggaran dan proses bisnis organisasi penyelenggara pelatihan.

Badan Pendidikan dan Pelatihan Keuangan (BPPK) merupakan eselon satu di bawah Kementerian Keuangan yang menyelenggarakan pendidikan dan pelatihan untuk mendukung peningkatan kompetensi Aparatur Sipil Negara di bidang keuangan negara. BPPK dipilih sebagai unit analisis karena saat ini sedang bertransformasi dalam penyelenggaraan pelatihan untuk lebih banyak melaksanakan pelatihan dalam bentuk $e$ learning (BPPK, 2019). Pelaksanaan e-learning di BPPK merupakan salah satu upaya efisiensi dan inisiatif strategis pada tema transformasi digital sesuai dengan KMK 302/KMK.01/2019 tentang Implementasi Inisiatif Strategis Program Reformasi dan Transformasi Kelembagaan Kementerian Keuangan.

Pelatihan e-learning berdasarkan Peraturan Kepala BPPK diselenggarakan dengan bentuk synchronous dan asynchronous. E-learning synchronous yaitu e-learning yang dilaksanakan dengan membutuhkan dukungan pihak lain (facilitated-led) dan menggunakan metode komunikasi dua arah di waktu tertentu (real time) serta terikat pada jadwal yang ketat. E-learning asynchronous yaitu e-learning yang dilaksanakan secara individual (selfpaced) maupun dukungan pihak lain pada waktu mandiri (time independent) dan tidak terikat pada jadwal yang ketat. Pelaksanaan e-learning menggunakan portal pembelajaran yang dikelola BPPK yaitu Kemenkeu Learning Center (https://klc.kemenkeu.go.id/ dan https://klc2.kemenkeu.go.id/). 
New Public Management (NPM) menjadi referensi reformasi yang terjadi di organisasi publik. Dengan NPM, sektor publik diarahkan untuk melaksanakan manajemen profesional gaya swasta dalam menyelenggarakan pemerintahan (Hood, 1991). Menurut Wright (1991), tujuan utama dari reformasi NPM adalah untuk meningkatkan efektivitas dan efisiensi sektor publik, meningkatkan daya tanggap organisasi publik terhadap klien dan pelanggan mereka, mengurangi pengeluaran dan meningkatkan akuntabilitas manajerial (Boustani \& Chedrawi, 2019). NPM menuntut reformasi cara pemerintah mengelola kegiatan yang difokuskan pada efisiensi yaitu menghasilkan lebih banyak kegiatan dengan biaya minimal kemudian bertanggung jawab kepada masyarakat atas sumber daya digunakan (BuneaBontas dan Petre, 2011).

NPM pada sektor publik juga berpengaruh kepada perubahan sistem anggaran. Penganggaraan dalam perspektif NPM menitikberatkan orientasi pada outcome yang kemudian diwujudkan melalui penganggaran berbasis kinerja (Indrawati, 2010). Harun et al., (2013) menyatakan bahwa penerapan penganggaran berbasis kinerja sebagai bagian dari praktik NPM telah dilaksanakan di berbagai negara berkembang antara lain Malaysia (Saleh, 2007), Fiji (Sharma dan Lawrence, 2008) dan Indonesia (Harun dan Robinson, 2010).

Dalam rangka pelaksanaan e-learning di BPPK, penyusunan anggaran merupakan proses yang penting untuk dilaksanakan. Proses perencanaan dan penganggaran merupakan tahapan penting dalam pelaksanaan APBN, sehingga anggaran yang disusun harus mencerminkan kebutuhan pelaksanaan program dan kegiatan untuk dapat meningkatkan efisiensi belanja pemerintah. Terdapat hubungan positif antara perencanaan anggaran dengan penyerapan anggaran (Wahab, 2019). Oleh sebab itu, perencanaan anggaran yang tidak mencerminkan kebutuhan yang sebenarnya terdapat kemungkinan terjadinya inefisiensi penganggaran atau malah kurangnya anggaran yang dibutuhkan untuk pelaksanaan kegiatan.

Pada buku Pedoman Penerapan Penganggaran Berbasis Kinerja (PBK) yang dikeluarkan oleh Departemen Keuangan Republik Indonesia dan Badan Perencanaan Pembangunan Nasional (2009) disebutkan bahwa dalam penyusunan anggaran berbasis kinerja diperlukan tiga komponen yaitu indikator kinerja, standar biaya, dan evaluasi kinerja. Standar biaya tersebut diartikan sebagai alat bantu dalam penyusunan anggaran dan merupakan kebutuhan anggaran yang paling efisien untuk menghasilkan keluaran.

Standar Biaya Keluaran (SBK) diperlukan dalam proses penyusunan anggaran. SBK pelatihan BPPK termasuk dalam kategori SBK khusus. SBK khusus disusun oleh PA/KPA untuk kemudian diusulkan kepada Direktur Jenderal Anggaran (DJA) untuk ditelaah dan ditetapkan setiap tahun anggaan melalui PMK tentang Standar Biaya Keluaran. Namun, SBK pelatihan terakhir kali diusulkan oleh BPPK untuk tahun anggaran 2018. Padahal sejak tahun 2019, BPPK menjalani transformasi birokrasi dengan target melaksanakan pelatihan melalui e-learning sebesar 30\% dari total pelatihan. Target tersebut meningkat menjadi $50 \%$ pada tahun 2020 dan $70 \%$ pada tahun 2021 dari total pelatihan yang diselenggarakan.

Dari sisi pelaksanaan program pelatihan e-learning, pada tahun 2019 telah melampaui target yang ditetapkan oleh Menteri Keuangan sebesar 30\% dari total pelatihan yang diselenggarakan sebagaimana yang terdapat dalam dokumen implementasi e-learning (BPPK, 2019). Namun, dalam pelaksanaannya e-learning terdapat perbedaan anggaran yang dibutuhkan oleh masing-masing Pusdiklat yang berada di BPPK. Berdasarkan dokumen anggaran yaitu Petunjuk Operasional Kegiatan (POK) tahun 2019 yang ditampilkan pada tabel 1., dapat disimpulkan bahwa perbedaan indeks biaya per peserta atas anggaran pelatihan e-learning yang disusun oleh masing-masing Pusdiklat. Perbedaan tersebut menunjukkan bahwa adanya ketidakseragaman anggaran dalam tahap perencanaan anggaran pelatihan e-learning. 
Tabel 1. Perbandingan Anggaran Pelatihan E-Learning dalam Dokumen Anggaran Pusdiklat T.A. 2019

\begin{tabular}{llrrr}
\hline No. & \multicolumn{1}{c}{ Penyelenggaran } & $\begin{array}{r}\text { Anggaran } \\
\text { E-learning } \\
\text { (Rupiah) }\end{array}$ & $\begin{array}{r}\text { Jumlah } \\
\text { peserta }\end{array}$ & $\begin{array}{c}\text { Indeks biaya } \\
\text { per peserta } \\
\text { (Rupiah) }\end{array}$ \\
\hline 1. & Pusdiklat Anggaran dan Perbendaharaan (AP) & 9.900 .000 & 1.500 & 6.600 \\
2. & Pusdiklat Keuangan Umum (KU) & 257.942 .000 & 2.000 & 128.971 \\
3. & Pusdiklat Kekayaan Negara dan Perimbangan Keuangan & 9.265 .000 & 753 & 12.304 \\
4. & Pusdiklat Pajak & 113.340 .000 & 613 & 184.894 \\
5. & Pusdiklat Bea dan Cukai (BC) & 36.854 .000 & 1.960 & 18.803 \\
6. & Pusdiklat Pengembangan Sumber Daya Manusia (PSDM) & 271.152 .000 & 300 & 903.840 \\
\hline
\end{tabular}

Sumber: BPPK (2019), telah diolah.

Perbedaan kebutuhan anggaran pelatihan e-learning terjadi karena karena usulan standar biaya yang telah disusun saat ini belum mencerminkan sepenuhnya seluruh biaya penyelenggaraan e-learning antara lain biaya pembuatan konten pembelajaran yang seharusnya termasuk ke dalam tahap perencanaan e-learning tidak diperhitungkan dalam penghitungan indeks biaya per peserta. Akar permasalahan lain dalam rangka maksimalisasi efisiensi anggaran pelatihan adalah struktur organisasi yang ada saat ini belum sepenuhnya mendukung pelaksanaan pelatihan e-learning. Belum terdapat unit yang mempunyai tugas dan fungsi terkait penyusnan konten pembelajaran multimedia. Oleh sebab itu, dalam rangka penyusunan konten e-learning dalam bentuk multimedia (audio, visual, dan/atau audio visual), terdapat perbedaan di masing-masing Pusdiklat. Terdapat pusdiklat yang membentuk tim penyusun konten yang berasal dari internal maupun tenaga honorer, sedangkan Pusdiklat lain yang menggunakan jasa vendor dalam rangka pembuatan tersebut sehingga mengeluarkan biaya yang lebih mahal.

Penelitian ini bertujuan untuk mengetahui dampak e-learning terhadap anggaran pelatihan, analisis perbandingan standar biaya keluaran pelatihan klasikal dan e-learning, dan penyusunan standar biaya keluaran e-learning sesuai dengan komponen pembentuk biaya yang diperlukan untuk menyelenggarakan e-learning. Pendekatan logic model digunakan untuk mengidentifikasi input, proses, output dan outcome dari pelatihan dalam bentuk e-learning. Program logic merupakan salah satu mekanisme yang dapat menghubungkan anggaran dengan kinerja. Konsep logic model digunakan dalam bidang perencanaan dan penganggaran karena dapat menunjukkan berapa banyak uang yang diarahkan untuk mencapai hasil tertentu dengan menyusun kerangka logis input, aktivitas, output, dan outcome (Oktaviani, 2016). Penelitian ini menggunakan logic model dalam menganalisis secara spesifik pelaksanaan pelatihan e-learning sehingga diketahui aktivitas yang membentuk biaya pelatihan dan pengaruh yang dihasilkan oleh pelatihan terhadap proses bisnis dan anggaran pelatihan di BPPK.

Hasil penelitian menunjukkan bahwa penyelenggaraan pelatihan e-learning secara signifikan dapat menghemat anggaran pelatihan dan meningkatkan jumlah peserta yang dapat dilatih. Namun, standar biaya yang disusun saat ini belum optimal karena belum mencerminkan seluruh biaya yang diperlukan untuk menyelenggarakan e-learning. Standar biaya yang disusun sebaiknya dibedakan sesuai jenis pelatihan e-learning. Selain itu, untuk meningkatkan efisiensi anggaran atas pelaksanaan e-learning diperlukan penyesuaian kebutuhan kompetensi SDM dan struktur organisasi yang ada saat ini yang lebih sesuai dengan proses bisnis pelatihan e-learning.

Penelitian ini diharapkan dapat memberikan masukan terkait penyusunan standar biaya keluaran pelatihan e-learning yang dibutuhkan dalam rangka kegiatan penganggaran dan rekomendasi dalam untuk meningkatkan efisiensi anggaran bagi unit analisis secara khusus. Penelitian ini juga dihadapkan dapat memberikan contoh model terbaik bahwa transformasi digital dalam kegiatan pemerintahan dapat memberikan efisiensi anggaran 
dan diperlukannya reformasi birokrasi untuk mendapatkan lebih banyak manfaat atas hal tersebut.

\section{METODE PENELITIAN}

Penelitian ini merupakan penelitian yang dilaksanakan dengan pendekatan kualitatif. Pendekatan kualitatif dipilih karena menghasilkan informasi yang memberikan gambaran yang menyeluruh atas perbandingan dari segi anggaran dan proses bisnis atas penyelenggaraan pelatihan dalam bentuk e-learning dan klasikal yang diteliti di BPPK. BPPK menetapkan kebijakan terkait peraturan tentang pelaksanaan e-learning dan anggaran untuk unit eselon di bawahnya. Penulis menyadari bahwa BPPK menyelenggarakan pelatihan yang luas dan kompleks cakupannya, oleh sebab itu penelitian ini menggunakan pendekatan studi kasus dengan unit analisis di Pusdiklat Kekayaan Negara dan Perimbangan Keuangan (KNPK). Pusdiklat KNPK merupakan salah satu satuan kerja setingkat eselon dua yang berada di bawah BPPK yang melaksanakan pelatihan di bidang kekayaan negara dan perimbangan keuangan antara lain rumpun pelatihan terkait pengelolaan barang milik negara, lelang, piutang negara dan perimbangan keuangan pusat dan daerah. Struktur organisasi yang terdapat pada Pusdiklat KNPK terdiri dari bagian tata usaha, bidang perencaanan dan pengembanan diklat, bidang penyelenggaraan, bidang evaluasi dan pelaporan kinerja, dan kelompok jabatan fungsional widyaiswara. Pemilihan Pusdiklat KNPK sebagai unit analisis dalam penelitian studi kasus ini sudah mewakili unit analisis secara umum karena pelaksanaan e-learning pada Pusdiklat lain menggunakan peraturan dan pedoman terkait anggaran dan pelatihan e-learning yang dikeluarkan oleh Sekretariat BPPK. SBK pelatihan e-learning yang saat ini telah disusun oleh Bagian Keuangan Sekretariat BPPK yang digunakan sebagai dokumen sumber dalam penelitian ini juga berlaku untuk semua Pusdiklat.

Studi kasus menurut Yin (2015) merupakan salah satu metode penelitian ilmu sosial dan strategi yang lebih cocok apabila pertanyaan penelitian berkenaan dengan how dan why, sangat sedikit kontrol atas peristiwa-peristiwa yang akan diselidiki, dan fokus penelitian merupakan fenomena kontemporer (masa kini) dalam konteks kehidupan nyata. Studi kasus dilakukan dengan menghubungi BPPK, khususnya unit yang menyelenggarakan pelatihan e-learning yaitu Pusdiklat KNPK yang menjadi objek dalam penelitian ini. Selanjutnya dilakukan komunikasi dengan panitia penyelenggara pelatihan maupun bagian keuangan untuk menggali lebih lanjut perbedaan antara pelatihan yang diselenggarakan secara klasikal dengan pelatihan e-learning baik dari anggaran maupun proses bisnis yang dilaksanakan. Penelitian dilakukan dengan mengumpulkan informasi-informasi yang relevan melalui wawancara dengan panitia penyelenggara pelatihan dan unit terkait lainnya, serta didukung dengan analisis atas dokumen keuangan dan laporan penyelenggaraan pelatihan.

Penelitian ini menggunakan data primer dan sekunder. Data primer diperoleh melalui observasi dan wawancara dengan para responden dan didokumentasikan melalui perekaman dan pencatatan. Wawancara dilaksanakan dalam bentuk semi-structured yaitu poin pertanyaan yang telah ditentukan sebelumnya dengan referensi yang berasal dari landasan teori yang telah diuraikan. Lima tahapan wawancara yang dilakukan pada penelitian ini berdasarkan tahapan wawancara menurut Wilkinson dan Birmingham (2003) yaitu draft the interview, pilot your questions, select your interviewees, conduct the interviews, dan analyse the interview data. Pilot test yang dilakukan memberikan saran perbaikan terhadap poin pertanyaan yang telah disusun sebelumnya.

Pemilihan responden menggunakan metode purposive sampling yaitu pengambilan sampel dengan cara memilih sampel yang spesifik agar menghasilkan data yang cukup dan relevan yang menjawab tujuan penelitian (Yin, 2016). Pemilihan responden dalam penelitian 
ini didasarkan pada struktur organisasi unit analisis yang mempunyai tugas dan fungsi terkait penyelenggaraan pelatihan dan perumusan kebijakan terkait penganggaran di lingkungan BPPK. Alasan pemilihan responden dalam wawancara penelitian ini adalah responden merupakan pejabat atau pegawai yang terlibat langsung dalam penyelenggaraan pelatihan. Selain itu, responden mewakili masing-masing bagian/bidang pada struktur organisasi yang terdapat pada Pusdiklat KNPK dan bagian keuangan pada sekretariat BPPK. Hasil wawancara diintegrasikan dalam tahap analisis data untuk mendukung analisis yang berasal dari instrumen telaah dokumen dan observasi guna memastikan triangulasi data.

Data sekunder yang digunakan berupa peraturan, pedoman, laporan dan dokumen lain yang relevan dan dapat melengkapi informasi yang berasal dari data primer. Telaah dokumen dilakukan terhadap data sekunder yang diperoleh oleh peneliti melalui studi lapangan. Dokumen digunakan sebagai pelengkap atas data yang diperoleh dari hasil wawancara. Telaah dokumen dilakukan secara manual atas dokumen penganggaran antara lain standar biaya dan Petunjuk Operasional Kegiatan (POK), dokumen terkait pengadaan barang/jasa, laporan-laporan antara lain kajian pelaksanaan e-learning, laporan penyelenggaraan pelatihan, dan laporan realisasi keuangan, laporan kinerja, serta peraturan dan pedoman pelaksanaan pelatihan e-learning.

Analisis data yang digunakan dalam penelitian ini adalah analisis deskriptif. Berdasarkan penjelasan Yin (2016) tentang analisis data dalam penelitian kualitatif, analisis data pada penelitian ini terdiri dari lima tahapan yaitu compiling, disassembling, reassembling, interpreting, dan concluding. Analisis data dimulai dengan mengkompilasi dan memilah catatan lapangan yang dikumpulkan (compiling). Catatan yang ada akan diurutkan secara formal dalam urutan yang bermanfaat dan dianggap sebagai database (Yin, 2016). Pada tahap ini, dilakukan kompilasi atas data dikumpulkan oleh peneliti dari berbagai laporan (antara lain laporan kinerja, laporan keuangan, laporan penyelenggaraan diklat, dan laporan kajian pelaksanaan pelatihan dalam bentuk e-learning), dokumen (antara lain DIPA, Petunjuk Operasional Kegiatan (POK), dan dokumen administrasi penyelenggaraan pelatihan), dan peraturan terkait proses bisnis dan anggaran pelatihan dalam bentuk $e$ learning dan pelatihan dalam bentuk klasikal serta hasil wawancara dan observasi.

Tahap kedua dari analisis data, disassembling yaitu memecah data yang telah dikompilasi menjadi potongan-potongan yang lebih kecil yang akan diberikan kode pada setiap fragmen atau potongan tersebut (Yin, 2016). Pada tahap ini, data yang dikumpulkan melalui telaah dokumen dan observasi yang telah dikompilasi pada tahap sebelumnya dikategorikan menjadi dua label yaitu pelatihan klasikal dan pelatihan e-learning. Sedangkan hasil wawancara diberikan label berdasarkan responden, terdiri dari responden 1 (Bagian Tata Usaha), responden 2 (Bidang Perencanaan dan Pengembangan Diklat), responden 3 (Bidang Penyelenggaraan), responden 4 (Bidang Evaluasi dan Pelaporan Kinerja), responden 5 (widyaiswara/pengajar), dan responden 6 (Bagian Keuangan Sekretariat BPPK).

Tahap ketiga dari analisis data menurut Yin (2016) adalah reassembling yaitu terhadap potongan atau fragmen akan dikelompokkan dan diurutkan dengan menggunakan tema-tema substantif yang mungkin berbeda dengan urutan dalam catatan asli. Dalam penelitian ini, data yang telah dikelompokkan dan diberi label pada tahap sebelumnya dikelompokkan dan diurutkan kembali dengan tema berbeda dengan urutan dalam catatan asli dengan menggunakan konsep logic model yaitu input, aktivitas, output, dan outcome.

Tahap keempat analisis data menurut Yin (2016) adalah interpretasi atas data telah dikelompokkan. Dalam penelitian ini, masing-masing data berupa dokumen anggaran, laporan penyelenggaraan pelatihan, laporan realisasi, pedoman dan peraturan terkait dengan pelatihan serta hasil wawancara ditafsirkan dalam bentuk narasi. Tahap kelima 
menurut Yin (2016) merupakan tahap penutup yaitu mengambil kesimpulan dari seluruh penelitian yang dilakukan. Dalam penelitian ini, terhadap pertanyaan penelitian akan ditarik kesimpulan berdasarkan penelitian yang telah dilaksanakan.

Pada penelitian ini, analisis data untuk menjawab pertanyaan penelitian dapat digambarkan dalam kerangka tahapan analisis sebagaimana Gambar 1.

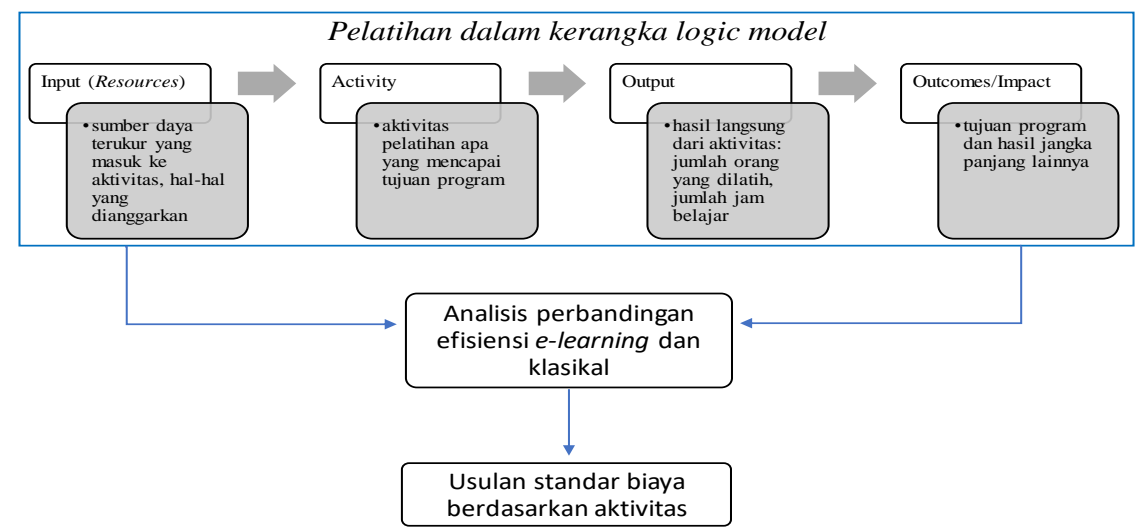

Gambar 1. Kerangka Tahapan Analisis

Sumber: U.S. Office of Personnel Management's Training and

Development dalam Brill (2016), telah diolah kembali.

\section{HASIL DAN PEMBAHASAN}

\section{Dampak E-Learning terhadap Anggaran Pelatihan}

Pada tahun 2020, target pelaksanaan e-learning sebesar 50\% dari total pelatihan yang dilaksanakan, namun sejak bulan Juli 2020 pelatihan yang diselenggarakan oleh Pusdiklat KNPK seluruhnya dilaksanakan dengan bentuk e-learning. Hal tersebut merupakan dampak dari social distancing yang diberlakukan dalam mencegah penyebaran COVID-19. Dapat dikatakan bahwa pandemi COVID-19 mendorong percepatan transformasi digital.

Terdapat peningkatan jumlah peserta pelatihan yang signifikan sejak diselenggarakannya pelatihan e-learning pada Pusdiklat KNPK yang menjadi objek penelitian studi kasus. Dari grafik 1. dapat dilihat bahwa pada tahun 2018, jumlah peserta yang dilatih mengalami peningkatan sebesar $6 \%$ dengan peningkatan anggaran sebesar $24 \%$ dibandingkan pada tahun 2017.

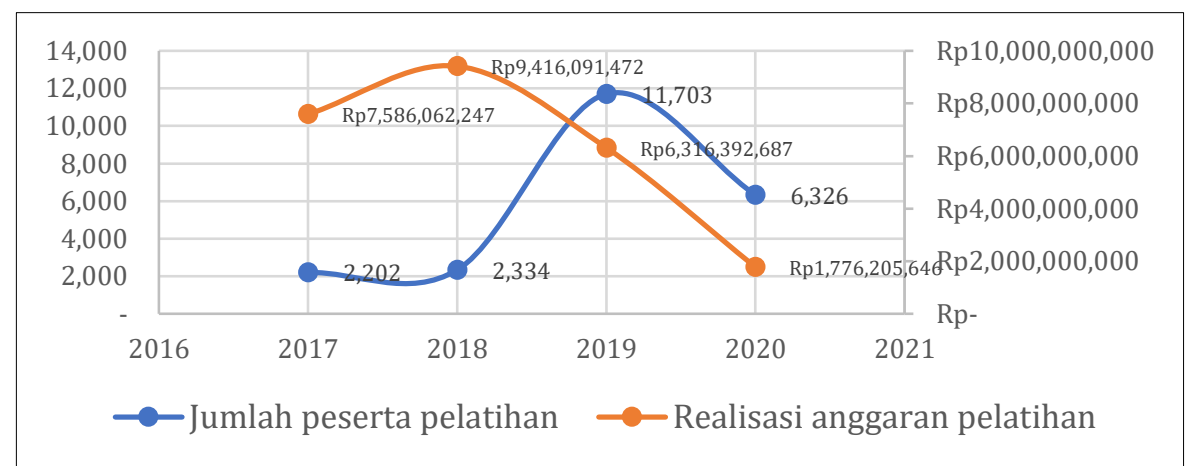

Grafik 1. Perbandingan Jumlah Peserta dan Realisasi Anggaran Pelatihan

Sumber: Laporan Kinerja Pusdiklat KNPK Tahun 2017 s.d. Triwulan III 2020, telah diolah kembali.

Pada tahun 2019, jumlah peserta yang dilatih mengalami peningkatan signifikan sebesar $400 \%$ dari tahun sebelumnya, namun dengan anggaran yang direalisasikan turun sebesar 33\% dari tahun 2018. Peningkatan yang signifikan pada tahun 2019 terjadi karena 
adanya target penyelenggaraan pelatihan e-learning sebanyak 30\% dari total jumlah pelatihan yang diselenggarakan.

Tabel 2. menyajikan data jumlah pelatihan klasikal dan e-learning dari total pelatihan regular yang dilaksanakan oleh Pusdiklat KNPK tahun 2017 s.d. triwulan III tahun 2020.

Tabel 2. Jumlah Pelatihan Klasikal dan E-Learning

\begin{tabular}{lcccc}
\hline \multicolumn{1}{c}{ Jenis Pelatihan } & 2017 & 2018 & 2019 & 2020 \\
\hline Pelatihan Klasikal & 100 & 102 & 72 & 25 \\
Pelatihan E-Learning/PJJ & - & - & 46 & 111 \\
Total & 100 & 102 & 118 & 136 \\
\hline
\end{tabular}

Sumber: Laporan Kinerja Pusdiklat KNPK Tahun 2017 s.d. Triwulan III 2020, telah diolah kembali.

Dalam pelatihan klasikal terdapat batas kapasitas peserta yang dapat dilatih untuk setiap kelas pelatihan klasikal terdapat batas kapasitas peserta yang dapat dilatih untuk setiap kelas yang diselenggarakan. Hal tersebut terungkap sebagaimana dalam kutipan wawancara berikut:

"Satu kelas rata-rata 30 orang, kurang/lebih dikit, dianggarkan menyusun kalender direncanakan per kelas 30 orang. Untuk 35 orang masih bisa, tapi kalau 40 tidak bisa dilaksanakan di kelas-kelas, harus di aula karena keterbatasan. Penguasaan kelas supaya bisa suara didengar oleh semua, kalau terlalu besar raungan pasti berbeda, ya 30 kalau terjadi sesuatu kalau digeser maksimal 35..." (Responden 5, 2020).

Melalui pelatihan e-learning, jumlah peserta yang dapat dijangkau untuk mengikuti pelatihan menjadi lebih besar dengan anggaran yang diperlukan lebih sedikit. Pada tahun 2020, target pelaksanaan pelatihan e-learning sebesar 50\% dari total pelatihan yang dilaksanakan, namun sejak bulan Juli 2020 pelatihan yang diselenggarakan oleh Pusdiklat KNPK seluruhnya dilaksanakan dengan bentuk pelatihan e-learning sebagai dampak dari social distancing yang diberlakukan dalam mencegah penyebaran Covid-19. Distance learning merupakan pelatihan klasikal yang dikonversi menjadi pelatihan e-learning karena terdampak Covid-19. Dapat dikatakan bahwa pandemi Covid-19 mendorong percepatan transformasi digital. Hal ini sesuai dengan penelitian yang dilakukan oleh Bogdandy et al. (2020) dan livari et al. (2020).

Berdasarkan hasil wawancara, pembatalan pelatihan klasikal pada tahun 2020 karena pandemi COVID-19 juga menyebabkan penghematan anggaran sebesar Rp1.745.200.000 dari total pagu anggaran sebesar Rp5.860.043.000 atau sebesar 30\% yang sebagian berasal dari kontrak pengadaan atas jasa konsumsi dan akomodasi dalam rangka penyelenggaraan pelatihan klasikal (Responden 1, 2020). Sejak pelaksanaan e-learning mulai tahun 2019, tercatat perubahan besaran realisasi biaya pengadaan atas kontrak terkait pelatihan dapat dilihat pada tabel 3 .

Tabel 3. Realisasi Kontrak Pengadaan terkait Pelatihan (dalam Rupiah)

\begin{tabular}{crrrr}
\hline Pengadaan & \multicolumn{1}{c}{2017} & \multicolumn{1}{c}{2018} & \multicolumn{1}{c}{2019} & \multicolumn{1}{c}{2020} \\
\hline Tas Peserta & 358.591 .200 & 259.061 .000 & - & - \\
Konsumsi & 2.951 .925 .150 & 3.006 .868 .300 & 1.612 .983 .925 & 521.345 .100 \\
Bahan Ajar & 278.197 .537 & 305.762 .223 & - & - \\
Laundry & 399.515 .600 & 491.113 .590 & 286.107 .790 & 82.763 .900 \\
ATK Peserta dan & 295.318 .364 & 370.741 .030 & 253.501 .600 & 368.688 .870 \\
Penyelenggaraan Diklat & 304.178 .160 & 55.909 .755 & 93.076 .830 & 99.490 .875 \\
Perlengkapan Asrama Peserta & 4.587.726.011 & 4.489.455.898 & $\mathbf{2 . 2 4 5 . 6 7 0 . 1 4 5}$ & $\mathbf{1 . 0 7 2 . 2 8 8 . 7 4 5}$ \\
Total realisasi anggaran & Sumber: Pusdiklat KNPK(Data diolah) &
\end{tabular}


Tabel 3. Menunjukkan bahwa realisasi kontrak pengadaan terkait pelatihan terus mengalami penurunan. Pada tahun 2019, selain melaksanakan e-learning sebagai upaya efisiensi, BPPK juga mengeluarkan beberapa kebijakan. Dalam rangka meningkatkan efisiensi anggaran pelatihan, BPPK mengeluarkan beberapa kebijakan yaitu tidak memberikan bahan ajar dalam bentuk hardcopy kepada peserta dan menggantikan tas yang sebelumnya diberikan dalam bentuk backpack menjadi goody bag kepada peserta pelatihan klasikal. Pada tahun 2019 terjadi penurunan nilai pengadaan terkait pelatihan sebesar 50\%, namun dengan jumlah peserta pelatihan meningkat sebesar $400 \%$ dibandingkan dengan tahun 2018. Kebijakan tersebut dan pelaksanaan e-learning berpengaruh signifikan terhadap efisiensi anggaran dalam penyelenggaraan pelatihan di Pusdiklat KNPK. Pelaksanaan pelatihan e-learning pada organisasi pemerintah sesuai dengan konsep New Public Management yang menitikberatkan pada efisiensi organisasi pelatihan pemerintah.

\section{Analisis Perbandingan Standar Biaya Keluaran Pelatihan E-Learning dan Pelatihan Klasikal}

Dalam menyelenggarakan tugas dan fungsi untuk melaksanakan pendidikan, pelatihan dan sertifikasi di bidang keuangan negara, BPPK berpedoman pada Standar Biaya Masukan (SBM) yang ditetapkan oleh Menteri Keuangan melalui PMK untuk setiap tahun anggaran. Selain itu, BPPK juga mengeluarkan pedoman terkait penggunaan SBM Lainnya (SBML) di lingkungan BPPK. Dalam rangka kegiatan penganggaran, BPPK juga menyusun usulan SBK terkait pelatihan di BPPK. SBK tersebut disusun dengan menggunakan SBM sebagai penyusun biaya komponen keluaran. Total biaya keluaran untuk jenis pelatihan yang dihasilkan akan dibagi dengan jumlah keluaran sehingga menghasilkan indeks biaya keluaran. Pada tahun anggaran 2021, usulan SBK telah disusun oleh Subbagian Anggaraan BPPK. SBK pelatihan tersebut tidak termasuk dalam lampiran PMK tentang SBK Tahun Anggaran 2021 karena belum ditelaah oleh DJA Kementerian Keuangan.

Pelatihan klasikal dilaksanakan dengan dua bentuk yaitu tidak diasramakan atau diasramakan (asrama internal dan eksternal) dengan hari penyelenggaraan mulai dari 3 hari hingga 33 hari. Untuk dapat melihat perbandingan standar biaya keluaran antara pelatihan klasikal dan pelatihan e-learning, pembahasan dalam penelitian ini dibatasi pada pelatihan klasikal yang diselenggarakan selama lima hari pada asrama internal. Pembatasan ini dilakukan karena SBK e-learning dan distance learning yang saat ini disusun oleh Bagian Keuangan menggunakan asumsi penyelenggaraan lima hari kerja dengan 30 orang peserta. Sesuai dengan komponen usulan SBK T.A. 2021 yang disusun oleh Bagian Keuangan BPPK, total anggaran pelatihan klasikal yang diselenggarakan 3 s.d. 5 hari di asrama internal adalah sebesar Rp51.520.300.

Pelatihan e-learning sesuai dengan usulan SBK T.A. 2021 membutuhkan anggaran sebesar adalah Rp4.480.000 (asumsi 30 orang peserta) dengan indeks biaya per peserta sebesar Rp149.333, sedangkan biaya pelatihan jarak jauh membutuhkan anggaran sebesar Rp10.305.000 (asumsi 30 orang peserta) dengan indeks biaya per peserta sebesar Rp343.500. Perbedaan antara total anggaran yang dibutuhkan untuk menyelenggarakan pelatihan e-learning dan distance learning terjadi karena jumlah jam pelatihan yang lebih banyak pada distance learning. Hal tersebut terjadi karena distance learning merupakan pelatihan yang seharusnya masih dilaksanakan dengan bentuk klasikal, namun karena pandemi Covid-19 dilaksanakan melalui online learning

Sesuai dengan dokumen usulan Standar Biaya Keluaran (SBK) Pelatihan, perbandingan antara komponen biaya pelatihan klasikal, e-learning dan distance learning yang secara umum terdiri dari tiga tahapan dapat dilihat pada tabel 4. di bawah ini. 
Tabel 4. Komponen Biaya pada Usulan SBK Pelatihan Klasikal dan E-Learning

\begin{tabular}{|c|c|c|}
\hline Tahapan & Komponen Biaya Pelatihan Klasikal & $\begin{array}{c}\text { Komponen Biaya E-Learning } \\
\text { dan Distance Learning }\end{array}$ \\
\hline $\begin{array}{l}\text { Persiapan } \\
\text { Pelatihan }\end{array}$ & $\begin{array}{l}\text { Biaya konsumsi rapat pengajar } \\
\text { Biaya transport rapat pengajar } \\
\text { Biaya penggandaan bahan ajar (termasuk modul) dan } \\
\quad \text { pedoman pelatihan } \\
\text { Biaya pengadaaan ATK dan perlengkapan peserta } \\
\text { Biaya pengadaan perlengkapan asrama peserta } \\
\text { Biaya pengadaan ATK Penyelenggaraan (kelas) } \\
\text { Biaya pengadaan bahan praktik pelatihan } \\
\text { Biaya pengadaan obat-obatan bagi peserta pelatihan }\end{array}$ & $\begin{array}{l}\text { Biaya konsumsi rapat pengajar } \\
\text { Biaya transport rapat pengajar }\end{array}$ \\
\hline $\begin{array}{l}\text { Pelayanan } \\
\text { Kelas }\end{array}$ & $\begin{array}{l}\text { Biaya seremonial pembukaan dan penutupan pelatihan } \\
\text { Biaya konsumsi peserta ( } 3 \text { kali makan/2 kali coffee } \\
\text { break) } \\
\text { Biaya konsumsi pengajar ( } 1 \text { kali makan/2 kali coffee } \\
\text { break) } \\
\text { Biaya konsumsi petugas piket ( } 1 \text { kali makan) } \\
\text { Biaya jasa laundry (sprei dan sarung bantal, selimut, bed } \\
\text { cover, handuk, pakaian harian) } \\
\text { Honorarium piket diklat diasramakan } \\
\text { Honorarium penceramah } \\
\text { Honorarium pengajar internal BPPK } \\
\text { Honorarium pengajar eksternal BPPK } \\
\text { Honorarium pengajar pakar/praktisi/tenaga profesi } \\
\text { Honorarium praktik kerja lapangan (pembimbing } \\
\text { lokasi, pembimbing makalah, dan tenaga medis) } \\
\text { Biaya transport pengajar dan penceramah }\end{array}$ & $\begin{array}{l}\text { Honorarium administrator } \\
\text { pelatihan e-learning atau } \\
\text { PIC distance learning } \\
\text { Honorarium penceramah } \\
\text { Honorarium pengajar internal } \\
\text { BPPK } \\
\text { Honorarium pengajar } \\
\text { eksternal BPPK } \\
\text { Honorarium pengajar } \\
\text { pakar/praktisi/tenaga } \\
\text { profesi } \\
\text { Biaya transport pengajar }\end{array}$ \\
\hline $\begin{array}{l}\text { Penilaian } \\
\text { Kompetensi }\end{array}$ & $\begin{array}{l}\text { Biaya konsumsi rapat kelulusan } \\
\text { Biaya transport rapat kelulusan } \\
\text { Biaya pencetakan naskah ujian } \\
\text { Biaya penggandaan laporan penyelenggaraan } \\
\text { Honorarium penyusunan materi ujian } \\
\text { (pembuat/penyusun materi ujian tertulis, validator, } \\
\text { pemeriksa hasil ujian, penguji praktik) } \\
\text { Honorarium tenaga teknis penunjang kegiatan (penata } \\
\text { kursi dan petugas kebersihan/keamanan/dan teknis } \\
\text { lainnya pada pelatihan menggunakan asrama } \\
\text { eksternal) }\end{array}$ & $\begin{array}{l}\text { Biaya konsumsi rapat } \\
\text { kelulusan } \\
\text { Biaya transport rapat } \\
\text { kelulusan } \\
\text { Biaya pencetakan naskah ujian } \\
\text { Honorarium penyusunan } \\
\text { materi ujian } \\
\text { (pembuat/penyusun materi } \\
\text { ujian tertulis, validator, } \\
\text { pemeriksa hasil ujian, } \\
\text { penguji praktik) }\end{array}$ \\
\hline
\end{tabular}

Sumber: BPPK (2020), telah diolah

Dari tabel 4 dapat dilihat bahwa terdapat perbedaan antara komponen biaya pelatihan klasikal dan e-learning. Berdasarkan tabel 4. dapat dilihat bahwa terdapat pengurangan biaya pada pelatihan e-learning yang berasal dari biaya yang bersifat variable cost pada pelatihan klasikal. Variable cost tersebut berubah sesuai dengan jumlah peserta antara lain biaya konsumsi, perlengkapan asrama, ATK, dan laundry. Komponen biaya yang masih terdapat pada pelatihan klasikal maupun e-learning umumnya bersifat fixed cost.

Berdasarkan komponen biaya pada SBK yang telah disusun oleh Bagian Keuangan saat ini, dapat dilihat bahwa untuk menyelenggarakan pelatihan selama lima hari, kebutuhan biaya pelatihan e-learning lebih efisien dibandingkan dengan pelatihan klasikal. Terdapat komponen biaya yang hilang ketika pelatihan dilaksanakan dalam bentuk elearning. Pelaksanaan e-learning sesuai dengan tujuan utama konsep NPM yang menekankan pada efisiensi kegiatan pemerintah. Transformasi digital yang dilakukan oleh BPPK untuk melaksanakan lebih banyak pelatihan e-learning memberikan efisiensi 
sebagaimana yang ditekankan pada reformasi NPM. Hal ini terlihat dari kutipan hasil wawancara sebagai berikut:

“... biaya delivery e-learning hanya membutuhkan sekitar 10\%-30\% anggaran dari penyelenggaraan pelatihan klasikal, bahkan jika dilihat dari realisasi anggaran elearning hanya mengeluarkan 4\%-5\% anggaran pelatihan klasikal..." (Responden 6, 2020).

Dari data yang dikumpulkan melalui wawancara, observasi dan telaah dokumen, analisis perbandingan pelatihan klasikal dan e-learning juga dilakukan dengan menggunakan kerangka logic model dapat dijelaskan sebagai berikut:

\section{Input}

Input adalah sumber daya terukur yang masuk ke aktivitas dan hal-hal yang dianggarkan (Brill, 2016). Pihak yang terlibat dalam pelatihan e-learning sama dengan pelatihan klasikal yaitu bagian tata usaha, bidang perencanaan dan pengembangan diklat, bidang penyelenggaraan, bidang evaluasi dan pelaporan kinerja, dan widyaiswara ataupun pengajar lainnya yang melaksanakan masing-masing melaksanakan kegiatan sesuai dengan tugas dan fungsinya. Pada pelatihan klasikal, bahan ajar berupa modul pelatihan yang sejak tahun 2019 diupayakan diberikan dalam bentuk softcopy kepada peserta pelatihan, sedangkan media pembelajaran e-learning berbentuk media multiplatform yang dapat berupa audio, visual dan/atau audio visual. Pembuatan media pembelajaran tersebut selain yang dapat disusun sendiri oleh pengajar, dapat melibatkan tim teknis yang dibentuk melalui Surat Keputusan (pengajar dan pegawai dari beberapa bidang yang memiliki kompetensi yang dibutuhkan) ataupun pengadaan melalui pihak ketiga. Hal ini terungkap dalam kutipan wawancara sebagai berikut:

“... Kalau yang model konten yang power point langsung widyaiswara yang membuat. Jika ada narasumber, tim kita merekam video. Jarang honor kepada untuk narasumber. Kalau video interaktif melibatkan vendor untuk pembuatannya.... Kalau konten yang ada interaktif lewat vendor. Untuk tim kita, pada periode 1 ada dibuat oleh SK oleh bidang renbang, terus dikeluarkan honornya..." (Responden 1, 2020).

Dari sisi biaya, tenaga kerja pada e-learning tetap dibayarkan sesuai dengan jam pelatihan yang terealisasi sama seperti pelatihan klasikal. Honorarium pengajar untuk pelatihan e-learning asynchronous tidak dibayarkan karena tidak ada interaksi antara pengajar dengan peserta pelatihan.

Biaya operasional penyelenggaraan pelatihan berkurang secara signifikan karena kelas diselenggarakan secara virtual. Namun, terdapat peningkatan biaya dari sisi pengembangan program/materi dan penyediaan sarana dan prasana penunjang pelatihan elearning sebagaimana yang terdapat dalam kutipan wawancara berikut.

"E-learning sangat efisien jika dari sisi delivery, namun terdapat biaya-biaya yang meningkat dari sisi pengembangan program/materi dan aspek penyediaan insfrastruktur. Namun dari pada itu, peningkatan biaya tersebut tidak sebesar dari efisiensi yang dihasilkan..." (Responden 6, 2020).

Berdasarkan hasil wawancara terungkap bahwa terdapat biaya yang seharusnya dapat dikeluarkan oleh Pusdiklat dalam pelaksanaan e-learning yaitu biaya bantuan pulsa. Hal ini sebagaimana yang terdapat dalam kutipan wawancara sebagai berikut: 
"Kalau PJJ mengeluarkan biaya untuk media yang digunakan. Bantuan pulsa lebih pada mengganti berbagai fasilitas yang selama ini diberikan (laundry, konsumsi) sekarang tidak ada, kebutuhan sekarang bandwith pulsa, sudah dihitung sebulan 200, seminggu 5oribu. Kebutuhan perhari berapa mega/gb. Kita sudah tidak memberikan bahan ajar hardcopy jadi sudah sangat efisien. Tidak keluar transpot, uang jajan untuk sekolah." (Responden 2, 2020).

\section{Activity}

Aktivitas pelatihan e-learning berbeda dengan pelatihan klasikal pada saat delivery pembelajarannya. Berdasarkan hasil wawancara, peserta dan pengajar pada metode $e$ learning synchronous dan distance learning berinteraksi langsung melalui zoom meeting dan/atau diskusi melalui media komunikasi seperti whatsapp group dan google classroom (Responden 2 dan 3, 2020). Berdasarkan hasil observasi interaksi tatap muka antara peserta dan pengajar juga dapat dilaksanakan melalui media video conference selain zoom meeting antara lain CloudX dari Telkomsel. Sedangkan, pada metode e-learning asynchronous peserta pelatihan belajar mandiri dengan menggunakan materi pembelajaran yang telah diberikan sebelumnya yang diupload pada platform pembelaran e-learning di BPPK yaitu KLC.

Berdasarkan hasil wawancara, pemilihan aktivitas dan media pembelajaran yang digunakan disesuaikan dengan tujuan program pelatihan yang didiskusikan dengan unit teknis pada saat rapat kurikulum (Responden 2, 2020). Kegiatan administrasi dan pelayanan kepada peserta tetap dilaksanakan oleh Bidang Penyelenggaraan, baik pada pelatihan klasikal maupun e-learning. Kegiatan evaluasi pembelajaran dilaksanakan pada pelatihan klasikal maupun e-learning sesuai dengan kurikulum yang telah ditetapkan.

\section{Output}

Jumlah jam pelatihan e-learning tidak berbeda dengan pelatihan klasikal, hanya saja terdapat pembatasan maksimal pada pelatihan e-learning. Pada pelatihan e-learning maksimal 3 jam pelatihan (jamlat) dalam satu hari, sedangkan pada distance learning untuk kegiatan tatap muka maksimal 5 jamlat dan non tatap muka maksimal 3 jamlat dalam satu hari.

Dari sisi jumlah peserta, pelatihan e-learning meningkatkan jumlah peserta yang dapat dilatih dibandingkan dengan pelatihan klasikal. Berdasarkan hasil wawancara diketahui bahwa pelatihan e-learning asynchronous yang bersifat open access dapat menampung lebih banyak peserta pelatihan karena tidak mempersyaratkan adanya penugasan dari instansi peserta. Berikut kutipan wawancara yang dimaksud.

"... Jumlah peserta lebih banyak adalah untuk yang open access karena tanpa surat tugas dari unit I masing-masing, kalau dari situ peserta banyak..." (Responden 4, 2020).

Dalam pelatihan klasikal terdapat batas kapasitas peserta yang dapat dilatih untuk setiap kelas yang diselenggarakan yaitu dengan jumlah ideal sebanyak 30 orang peserta. Melalui pelatihan e-learning, jumlah peserta yang dapat dijangkau untuk mengikuti pelatihan menjadi lebih besar dengan anggaran yang diperlukan lebih sedikit. Pelatihan elearning memberikan kapasitas yang lebih besar kepada BPPK untuk dapat menjangkau peserta lebih banyak dibandingkan pelatihan klasikal, baik dari Kementerian Keuangan maupun Kementerian/Lembaga lainnya dan Pemda, sehingga lebih mengoptimalkan tugas dan fungsi BPPK untuk menyelenggarakan pendidikan, pelatihan dan sertifikasi di bidang keuangan negara. Hal ini terungkap dari kutipan wawancara sebagai berikut: 
"E-learning sebenarnya kita bisa menjangkau lebih banyak. Kalau klasikal hanya yang ditugaskan saja, e-learning akan bisa diakses oleh pegawai kemenkeu khususnya dan K/L atau Pemda. BPPK mendidik bidang keuangan Pemda juga. Kalau klasikal akan kesulitan menjangkau semua. E-learning open access akan bisa diakses kapan saja dimana saja. Memaksimalkan tugas BPPK mendidik keuangan negara baik Kemenkeu dan non Kemenkeu." (Responden 4, 2020).

\section{Outcome/Impact}

Dengan melaksanakan e-learning, BPPK yang memiliki tugas untuk melaksanakan pelatihan di bidang keuangan negara dapat mencakup lebih luas peserta pelatihan dengan sumber daya dan waktu yang terbatas. Jika hanya mengandalkan pelatihan klasikal, maka kebutuhan tersebut tidak dapat tercapai karena terbatasnya sumber daya yang dimiliki. Hal ini terungkap dalam kutipan wawancara sebagai berikut:

“... Perubahan dari tradisonal menjadi corporate university, digitalisasi tidak bisa dihindari. Menjawab tantangan dari tuntutan jaman dan publik. BPPK harus bisa melayani seluruh K/L republik ini, bagaimana BPPK bisa melayani ASN yang bertugas di bidang kekayaan negara dan keuangan negara. Kalau dengan cara klasikal tidak dapat memenuhi kebutuhan pelatihan dengan konsidi SDM yang banyak..." (Responden 2, 2020).

"Dari sisi keuangan, penyelenggaraan e-learning bertujuan untuk melakukan efisiensi biaya..." (Responden 6, 2020).

Dari sisi efisiensi biaya berdasarkan analisis sebelumnya, pelatihan e-learning lebih unggul dari pelatihan klasikal. Namun, dari sisi efektivitas pembelajaran pelatihan klasikal saat ini lebih unggul dibandingkan dengan pelatihan e-learning. Dari sudut pandang peserta pelatihan, pelatihan e-learning memiliki kendala antara lain kendala teknis seperti jaringan komunikasi yang tidak stabil dan masih terbebani dengan tugas kantor sehingga mengganggu fokus dalam mengikuti e-learning. Permasalahan ini terungkap saat wawancara sebagaimana dikutip di bawah ini.

"... Jaringan peserta ini yang kadang menjadi hambatan karena jaringan kurang stabil, daerah yang memang tidak stabil..." (Responden 2, 2020)

"... kendala teknis seperti jaringan internet yang tidak stabil atau aliran listrik di beberapa daerah yang seringkali mengalami pemadaman yang berakibat pada penerimaan informasi yang kurang komprehensif. Masih banyak ditemui peserta pelatihan yang masih mendapat penugasan dari atasan untuk menyelesaikan pekerjaan kantor..." (Responden 3, 2020).

Dari perbandingan atas komponen pembentuk standar biaya dan analisis dalam kerangka logic model antara pelatihan klasikal dan e-learning, dapat dilihat bahwa terdapat beberapa komponen yang sebenarnya masih terdapat sebagai input di pelatihan e-learning, namun tidak dimasukkan ke dalam komponen usulan standar biaya pelatihan e-learning. Biaya tersebut antara lain biaya penyusunan bahan ajar dan biaya operasional terkait komunikasi peserta. Komponen biaya dalam usulan SBK pelatihan e-learning T.A. 2021 yang seharusnya sudah tidak termasuk sebagai komponen biaya adalah biaya pencetakan naskah ujian karena evaluasi terhadap peserta dilaksanakan secara online.

Selain itu, terdapat perbedaan jumlah jam pelatihan maksimal dalam sehari yang dapat dilaksanakan dalam pelatihan e-learning dan distance learning. Perbedaan aktivitas pembelajaran yang dilaksanakan juga berbeda untuk pelatihan e-learning synchronous dan asynchronous. Oleh sebab itu, standar biaya yang disusun sebaiknya dikategorikan untuk 
masing-masing jenis pelatihan e-learning (synchronous dan asynchronous) dan memasukkan seluruh komponen biaya yang dibutuhkan untuk menyelenggarakan pelatihan e-learning mulai dari tahap persiapan hingga evaluasi pelatihan.

\section{Analisis Penyusunan Standar Biaya Pelatihan E-Learning}

Kebutuhan biaya untuk melaksanakan suatu kegiatan, akan bergantung dari aktivitas yang dilaksanakan untuk mencapai tujuan kegiatan tersebut. Berdasarkan analisis perbandingan pelatihan klasikal dan e-learning dengan menggunakan kerangka logic model diketahui bahwa pada usulan SBK T.A. 2021 yang telah disusun saat ini, terdapat beberapa biaya yang dibutuhkan untuk menyelenggarakan e-learning, namun belum tercakup pada usulan standar biaya tersebut.

Salah satu biaya yang belum tercakup sebagai komponen biaya pada SBK T.A. 2021 yang disusun oleh Bagian Keuangan adalah terkait pembuatan modul pembelajaran berbasis digital (konten e-learning). Adapun pada tahun 2019, BPPK menyusun usulan standar biaya penyusunan materi pembelajaran e-learning untuk lima mata pelajaran secara swakelola sebesar Rp17.300.000 dan dengan menggunakan jasa pihak ketiga sebesar Rp94.330.000. Perbedaan tersebut muncul dari pembayaran kepada pihak ketiga sebesar Rp15.000.000 untuk setiap materi pelajaran yang disusun. Dasar alokasi yang digunakan menggunakan jumlah peserta (asumsi 30 orang peserta) sehingga indeks biaya per peserta menjadi Rp576.667 untuk swakelola dan Rp3.144.333 untuk pengembangan melalui pihak ketiga.

Dari analisis dengan menggunakan kerangka logic model, diketahui bahwa pada pelatihan e-learning asynchronous peserta belajar secara mandiri dari materi yang diberikan, dan tidak terdapat interaksi dengan pengajar. Selain itu, terdapat tambahan biaya karena aktivitas yang dilaksanakan pada pelatihan e-learning terutama untuk kegiatan tatap muka secara virtual. Biaya tersebut terkait dengan pelaksanaan pelatihan e-learning yang menggunakan jaringan komunikasi, sehingga peserta dapat diberikan biaya komunikasi sebagai pengganti biaya akomodasi yang biasanya diberikan pada pelatihan klasikal.

Usulan Standar Biaya Keluaran yang disusun dalam penelitian ini disimulasikan dengan menggunakan input SBM sesuai dengan standar biaya masukan lainnya (SBML) yang berlaku di lingkungan BPPK (2020) dan didasarkan pada biaya transaksi yang terjadi pada tiga tahapan penyelenggaraan e-learning yaitu sebagai berikut:

\section{Tahap Persiapan Program}

Aktivitas persiapan program e-learning secara umum sama dengan pelatihan klasikal. Perbedaan yang ada yaitu tidak dibutuhkannya biaya pengadaan ATK peserta dan penyelenggaraan (kelas) dan perlengkapan asrama peserta pelatihan. Rapat persiapan pengajar akan diselenggarakan sebelum dimulainya pelatihan. Pengadaan bahan ajar dan modul pelatihan merupakan komponen biaya dalam pelatihan klasikal, pada pelatihan $e$ learning berubah menjadi pengadaan konten pembelajaran. Pada usulan SBK yang disusun oleh BPPK saat ini, komponen tersebut belum dimasukkan kedalam perhitungan. Berdasarkan SBM Lainnya yang berlaku di BPPK, biaya-biaya yang diperkenankan untuk pembuatan konten pembelajaran terdiri dari honorarium penyusunan bahan ajar yang dibayarkan sesuai dengan jumlah halaman yang disusun dan honorarium konversi multimedia e-learning yang terdiri dari honorarium pembuat storyboard, fotorencgrafer/videografer, editor, dan desain grafis. Apabila terdapat unit kerja yang memiliki tugas dan fungsi terkait pembuatan konten multimedia, maka honorarium tidak akan dibayarkan dan akan memaksimalkan efisiensi anggaran yang dihasilkan dari penyelenggaraan e-learning dalam jangka panjang. Oleh sebab itu, unntuk dapat meningkatkan efisiensi anggaran dalam jangka panjang, diperlukan penyesuaian struktur organisasi dan kompetensi SDM di lingkungan BPPK yang lebih sesuai dengan proses bisnis 
penyelenggaraan e-learning sehingga penyusunan media pembelajaran dapat dilakukan secara swakelola. Hal ini juga terungkap dalam wawancara yang dikutip sebagai berikut.

“...Di Renbang butuh kompetensi teknologi pembelajaran, supaya kita gak usah ke vendor, jadi memproduksi e-learning itu satu kebutuhan keharusan. Cuma expertnya untuk menyusun ini belum ada..." (Responden 2, 2020).

Pengembangan konten pembelajaran yang dilakukan secara swakelola dengan menggunakan sumber daya yang tersedia di dalam unit kerja memberikan efisiensi anggaran yang lebih besar dibandingkan melalui pihak ketiga. Penyusunan konten pembelajaran melalui pihak ketiga sebaiknya didasarkan dengan jumlah materi e-learning yang disusun. Untuk dapat meningkatkan efisiensi anggaran, maka konten pembelajaran yang disusun melalui pihak ketiga merupakan materi pembelajaran yang dapat digunakan untuk pelatihan pada periode selanjutnya atau digunakan untuk lebih dari satu jenis pelatihan.

\section{Tahap Pelayanan E-Learning}

Aktivitas yang dilakukan pada tahap pelayanan e-learning membutuhkan biaya terkait honorarium pengajar dan administrator pelatihan e-learning. Pelayanan e-learning tidak membutuhkan biaya akomodasi seperti pada pelatihan klasikal, namun peserta pelatihan membutuhkan jaringan internet untuk dapat mengikuti pelatihan e-learning. Oleh sebab itu, dibutuhkan tambahan biaya bantuan komunikasi untuk mengakomodir peserta pelatihan dalam mengikuti pelatihan e-learning terutama yang memerlukan tatap muka secara virtual.

Usulan SBK masing-masing harus dibedakan untuk jenis pelatihan e-learning asynchronous, e-learning synchronous dan distance learning karena adanya perbedaan aktivitas terkait honorarium pengajar pelatihan. Pada e-learning asynchronous peserta pelatihan melakukan pembelajaran secara mandiri tanpa bantuan dari pengajar, oleh sebab itu tidak terdapat honorarium yang akan dibayarkan kepada pengajar. Pada e-learning synchronous kegiatan tatap muka maksimal dapat dilakukan sebanyak 3 jamlat dalam satu hari, sedangkan pelatihan distance learning kegiatan synchronous tatap muka maksimal dapat dilakukan sebanyak 5 jamlat dan synchronous non tatap muka maksimal dapat dilakukan sebanyak 3 jamlat dalam satu hari. Dengan demikian, biaya bantuan komunikasi yang diberikan untuk pelatihan e-learning synchronous dan distance learning akan berbeda.

\section{Tahap Penilaian Kompetensi}

Aktivitas penilaian kompetensi pada e-learning secara umum sama dengan pelatihan klasikal. Perbedaan yang ada yaitu tidak dibutuhkannya biaya pencetakan naskah ujian, biaya penggandaan laporan penyelenggaraan pelatihan, dan honorarium tenaga teknis penunjang kegiatan. Biaya tersebut tidak dibutuhkan pada penyelenggaraan e-learning karena ujian dilaksanakan dengan bantuan teknologi melalui platform pembelajaran. Namun, biaya pencetakan naskah ujian masih terdapat pada SBK yang disusun oleh Bagian Keuangan BPPK. Rapat kelulusan tetap diselenggarakan setelah berakhirnya pelatihan.

Rekomendasi usulan SBK pelatihan e-learning yang disusun dalam penelitian menggunakan input SBML untuk masing-masing jenis pelatihan terdiri dari pelatihan $e$ learning dan penyusunan konten pembelajaran melalui pihak ketiga.

Berdasarkan simulasi yang dilakukan pada tabel 8. di bawah ini, untuk dapat melaksanakan pelatihan e-learning asynchronous selama lima hari dibutuhkan total biaya sebesar Rp14.702.000. Indeks biaya keluaran yang disusun tidak didasarkan per jumlah peserta, namun diperhitungkan per program e-learning yang dilaksanakan karena peserta $e$ learning asynchronous terutama yang bersifat open access dapat diikuti oleh banyak peserta. 
Rakhmadina, Setyaningrum

Dampak E-Learning terhadap Anggaran Pelatihan Kementerian Keuangan

Tabel 8. SBK Pelatihan E-Learning Asynchronous

\begin{tabular}{|c|c|c|c|c|c|c|}
\hline Uraian & Rincian & Perhitungan & Volume & Satuan & Harga & Jumlah \\
\hline Persiapan Program & & & & & & 13.626 .000 \\
\hline \multicolumn{7}{|l|}{ Konsumsi Rapat } \\
\hline a. Makan & 5 Orang & 1 Kali & 5 & OK & 37.600 & 188.000 \\
\hline a. Snack & 5 Orang & 1 Kali & 5 & OK & 17.600 & 88.000 \\
\hline Transport Rapat (Dari Luar Kantor) & 2 Orang & x 1 Kali & 2 & OK & 150.000 & 300.000 \\
\hline $\begin{array}{l}\text { Honorarium Penyusunan Bahan Ajar Pelatihan } \\
\text { Honorarium Konversi Multimedia E-Learning }\end{array}$ & $5 \mathrm{MP}$ & x 20 halaman & 100 & Hal & 50.000 & 5.000 .000 \\
\hline a. Honorarium Pembuat Storyboard & 1 Orang & 5 Terbit & 5 & Oter & 1.000 .000 & 5.000 .000 \\
\hline b. Honorarium Fotografer/Videografer & 1 Orang & 5 Terbit & 5 & Oter & 180.000 & 900.000 \\
\hline c. Honorarium Editor & 1 Orang & 5 Terbit & 5 & Oter & 250.000 & 1.250 .000 \\
\hline d. Honorarium Desain Grafis & 1 Orang & 5 Terbit & 5 & Oter & 180.000 & 900.000 \\
\hline Pelayanan E-Learning & & & & & & 250.000 \\
\hline Honorarium Administrator Pelatihan E-Learning & 1 Orang & 5 Hari & 5 & $\mathrm{OH}$ & 50.000 & 250.000 \\
\hline Penilaian Kompetensi & & & & & & 826.000 \\
\hline \multicolumn{7}{|l|}{ Rapat Kelulusan } \\
\hline a. Makan & 5 Orang & 1 Kali & 5 & OK & 37.600 & 188.000 \\
\hline a. Snack & 5 Orang & 1 Kali & 5 & OK & 17.600 & 88.000 \\
\hline Transport Rapat (Dari Luar Kantor) & 2 Orang & 1 Kali & 2 & OK & 150.000 & 300.000 \\
\hline \multicolumn{7}{|l|}{ Honorarium Penyusunan Materi Ujian } \\
\hline a. Honorarium Pembuat/Penyusun Materi Ujian Tertulis & $1 \mathrm{MP}$ & 1 Frekuensi & 1 & $\mathrm{MpF}$ & 150.000 & 150.000 \\
\hline b. Honorarium Validator Materi Ujian Tertulis & $1 \mathrm{MP}$ & 1 Frekuensi & 1 & $\mathrm{MpF}$ & 100.000 & 100.000 \\
\hline \multicolumn{6}{|c|}{ Total Biaya } & 14.702 .000 \\
\hline \multicolumn{6}{|c|}{ Indeks Biaya per Program Pelatihan } & 14.702 .000 \\
\hline
\end{tabular}

Tabel 9. memberikan simulasi perhitungan usulan standar biaya pelatihan e-learning synchronous dengan asumsi hari penyelenggaraan pelatihan sepanjang lima hari dengan jumlah peserta sebanyak 30 orang. Berdasarkan simulasi yang dilakukan, untuk dapat melaksanakan pelatihan e-learning synchronous membutuhkan total anggaran sebesar Rp19.802.000 dengan indeks biaya per peserta sebesar Rp660.067.

Tabel 9. SBK Pelatihan E-Learning Synchronous

\begin{tabular}{|c|c|c|c|c|c|c|}
\hline Uraian & Rincian & Perhitungan & Volume & Satuan & Harga & Jumlah \\
\hline Persiapan Program & & & & & & 13.626 .000 \\
\hline \multicolumn{7}{|l|}{ Konsumsi Rapat } \\
\hline a. Makan & 5 Orang & 1 Kali & 5 & OK & 37.600 & 188.000 \\
\hline a. Snack & 5 Orang & 1 Kali & 5 & OK & 17.600 & 88.000 \\
\hline Transport Rapat (Dari Luar Kantor) & 2 Orang & x 1 Kali & 2 & OK & 150.000 & 300.000 \\
\hline \multicolumn{7}{|l|}{ Honorarium Konversi Multimedia E-Learning } \\
\hline a. Honorarium Pembuat Storyboard & 1 Orang & 5 Terbit & 5 & Oter & 1.000 .000 & 5.000 .000 \\
\hline b. Honorarium Fotografer/Videografer & 1 Orang & 5 Terbit & 5 & Oter & 180.000 & 900.000 \\
\hline c. Honorarium Editor & 1 Orang & 5 Terbit & 5 & Oter & 250.000 & 1.250 .000 \\
\hline d. Honorarium Desain Grafis & 1 Orang & 5 Terbit & 5 & Oter & 180.000 & 900.000 \\
\hline \multicolumn{3}{|l|}{ Pelayanan E-Learning } & & & & 5.350 .000 \\
\hline Honorarium Administrator Pelatihan E-Learning & 1 Orang & 5 Hari & 5 & $\mathrm{OH}$ & 50.000 & 250.000 \\
\hline Honorarium Pengajar Internal BPPK & 3 Orang & $3 \mathrm{JP}$ & 9 & OJ & 100.000 & 900.000 \\
\hline Honorarium Pengajar Eksternal & 2 Orang & $3 \mathrm{JP}$ & 6 & OJ & 200.000 & 1.200 .000 \\
\hline Biaya bantuan komunikasi & 30 Orang & 1 Kali & 30 & OK & 100.000 & 3.000 .000 \\
\hline \multicolumn{3}{|l|}{ Penilaian Kompetensi } & & & & 826.000 \\
\hline \multicolumn{7}{|l|}{ Rapat Kelulusan } \\
\hline a. Makan & 5 Orang & 1 Kali & 5 & OK & 37.600 & 188.000 \\
\hline a. Snack & 5 Orang & 1 Kali & 5 & OK & 17.600 & 88.000 \\
\hline Transport Rapat (Dari Luar Kantor) & 2 Orang & 1 Kali & 2 & OK & 150.000 & 300.000 \\
\hline \multicolumn{7}{|l|}{ Honorarium Penyusunan Materi Ujian } \\
\hline a. Honorarium Pembuat/Penyusun Materi Ujian Tertulis & $1 \mathrm{MP}$ & 1 Frekuensi & 1 & $\mathrm{MpF}$ & 150.000 & 150.000 \\
\hline \multirow[t]{2}{*}{ b. Honorarium Validator Materi Ujian Tertulis } & $1 \mathrm{MP}$ & 1 Frekuensi & 1 & $\mathrm{MpF}$ & 100.000 & 100.000 \\
\hline & al Biaya & & & & & 19.802 .000 \\
\hline \multicolumn{3}{|c|}{ Indeks Biaya per Peserta } & & & & 660.067 \\
\hline
\end{tabular}

Tabel 10. memberikan simulasi perhitungan usulan standar biaya pelatihan distance learning dengan asumsi hari penyelenggaraan pelatihan sepanjang lima hari dengan jumlah 
peserta sebanyak 30 orang. Berdasarkan simulasi yang dilakukan, untuk dapat melaksanakan pelatihan distance learning membutuhkan total anggaran sebesar Rp27.977.000 dengan indeks biaya per peserta sebesar Rp932.567.

Tabel 10. SBK Pelatihan E-Learning Distance Learning

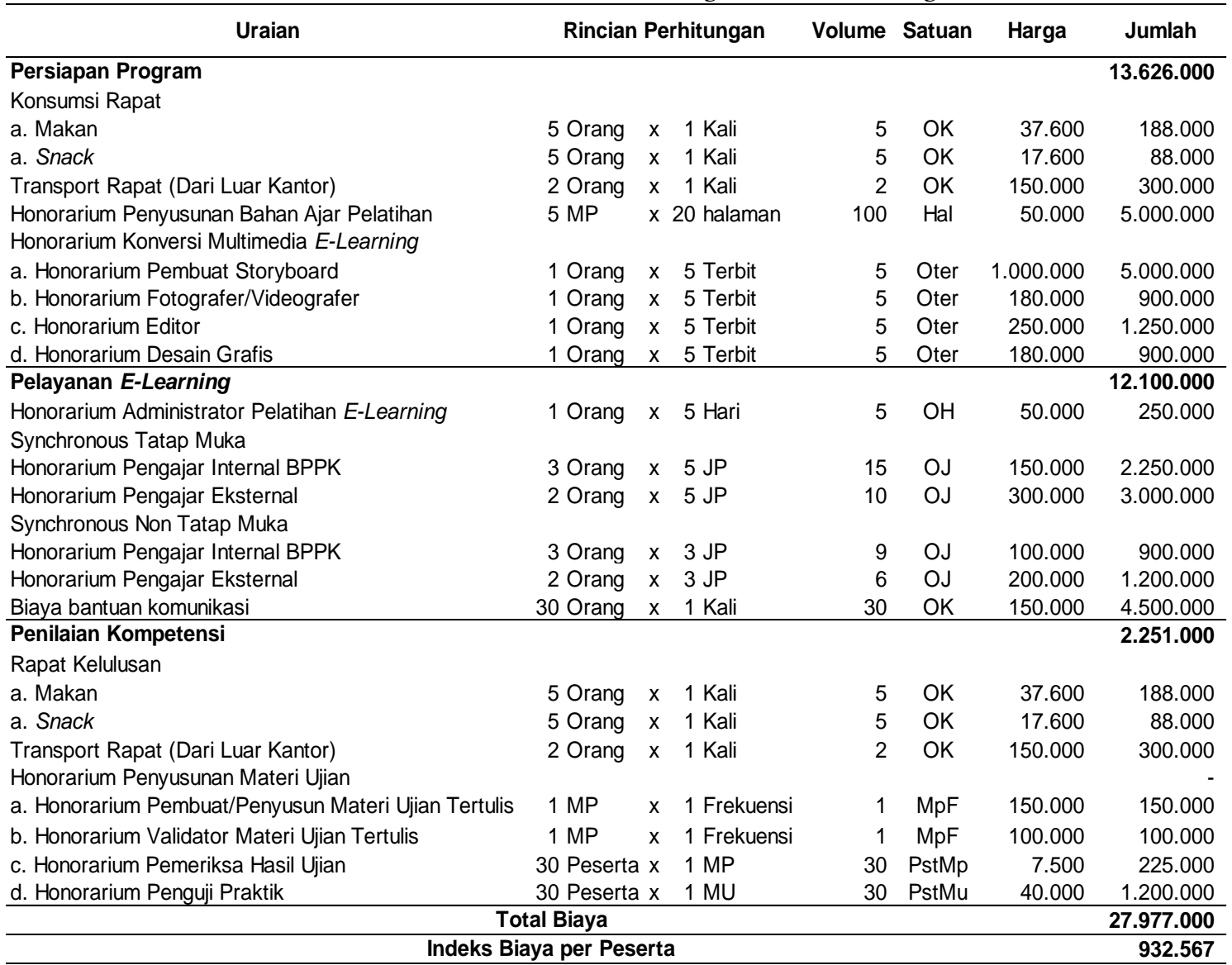

Tabel 7. memberikan simulasi perhitungan usulan SBK penyusunan konten pembelajaran melalui pihak ketiga dengan indeks biaya per materi pembelajaran sebesar Rp20.000.000.

Tabel 7. SBK Penyusunan Konten Pembelajaran melalui Pihak Ketiga

\begin{tabular}{|c|c|c|c|c|c|c|}
\hline Uraian & Rincian & Perhitungan & Volume & Satuan & Harga & Jumlah \\
\hline \multirow{2}{*}{$\begin{array}{c}\text { Honorarium Penyusunan Substansi Materi } \\
\text { Honorarium Narasumber Penyusunan } \\
\text { Substansi Materi }\end{array}$} & $1 \mathrm{MP}$ & 20 Halaman & 20 & $\mathrm{Hal}$ & 50.000 & 1.000 .000 \\
\hline & 1 Orang $x$ & $2 \mathrm{JP}$ & 2 & OJ & 1.000 .000 & 2.000 .000 \\
\hline $\begin{array}{c}\text { Honorarium Pengembangan Materi E- } \\
\text { Learning melalui Pihak Ketiga }\end{array}$ & $1 \mathrm{MP}$ & 1 Frekuensi & 1 & OJ & 15.000 .000 & 15.000 .000 \\
\hline $\begin{array}{c}\text { Honorarium Narasumber Review Uji } \\
\text { Kelayakan Hasil Produksi }\end{array}$ & 1 Orang $x$ & $2 \mathrm{JP}$ & 2 & OJ & 1.000 .000 & 2.000 .000 \\
\hline \multicolumn{6}{|c|}{ Total Biaya } & 20.000 .000 \\
\hline \multicolumn{6}{|c|}{ Indeks Biaya per Materi Pembelajaran } & 20.000 .000 \\
\hline
\end{tabular}

\section{KESIMPULAN}

Berdasarkan analisis dan pembahasan sebelumnya, dapat disimpulkan bahwa pelatihan e-learning memberikan dampak positif terhadap efisiensi anggaran pelatihan dibandingkan dengan pelatihan klasikal. Pelatihan e-learning menjangkau lebih banyak peserta dibandingkan dengan pelatihan klasikal. Selain itu, pandemi COVID-19 memaksa 
terjadinya transfomasi digital menjadi lebih cepat dan pada ruang lingkup yang lebih luas. Pelatihan yang seharusnya masih dilaksanakan dengan bentuk klasikal, dilaksanakan dalam bentuk distance learning sebagai akibat dari diberlakukannya kebijakan social distancing untuk dapat mencegah penularan COVID-19.

Dari analisis perbandingan standar biaya keluaran pelatihan e-learning dan pelatihan klasikal, standar biaya yang disusun saat ini belum optimal karena belum mencerminkan seluruh biaya yang diperlukan untuk menyelenggarakan e-learning. Penyusunan standar biaya seharusnya diperhitungkan berdasarkan aktivitas yang dibutuhkan untuk menyelenggarakan e-learning. Standar biaya keluaran yang disusun sebaiknya dibedakan untuk masing-masing jenis pelatihan yaitu pelatihan e-learning asynchronous, pelatihan $e$ learning synchronous, dan distance learning.

Hasil penelitian menunjukkan bahwa diperlukan penyesuaian struktur organisasi dan kebutuhan kompetensi SDM di BPPK yang mendukung proses bisnis penyelenggaraan $e$ learning, apabila ingin mencapai efisiensi anggaran yang maksimal atas pelaksanaan elearning. Perubahan struktur organisasi tersebut mendukung pelaksanaan transformasi digital maupun birokrasi yang dilaksanakan di lingkungan BPPK. Selain itu, SBK pelatihan klasikal dan e-learning yang sudah disusun oleh BPPK seharusnya diusulkan kepada Menteri Keuangan c.q. Direktur Jenderal Anggaran dengan mengikuti ketentuan yang berlaku. Direktorat Jenderal Anggaran melakukan penelaahan dan mengajukan usulan SBK hasil penelaahan untuk ditetapkan oleh Menteri Keuangan dalam PMK tentang Standar Biaya Keluaran.

Penulis menyadari bahwa penelitian ini masih memiliki keterbatasan. Jumlah responden yang diwawancara dalam penelitian ini masih terbatas yaitu lima orang yang berasal dari salah satu unit penyelenggaran pelatihan dan satu orang dari unit pembuat kebijakan anggaran di BPPK, sehingga dimungkinkan banyak informasi yang belum tergali dengan optimal. Penelitian selanjutnya dapat melakukan penambahan jumlah responden.

Lingkup penelitian ini juga terbatas pada penggunaan konsep logic model dalam tahap penyusunan standar biaya keluaran pelatihan e-learning untuk penganggaran di Badan Pendidikan dan Pelatihan Keuangan. Penelitian selanjutnya dapat melakukan evaluasi atas penggunaan standar biaya keluaran dalam tahap pelaksanaan APBN di lingkungan pemerintah pusat.

\section{DAFTAR PUSTAKA}

Aparicio, M., Bacao, F., \& Oliveira, T. (2016). An e-learning theoretical framework. Educational Technology and Society, 19, 292-307. https://doi.org/10.2307/jeductechsoci.19.1.292

Bogdandy, B., Tamas, J., \& Toth, Z. (2020). Digital transformation in education during COVID19: A case study. 11th IEEE International Conference on Cognitive Infocommunications, CogInfoCom $2020 \quad$ Proceedings, $173-178$. https://doi.org/10.1109/CogInfoCom50765.2020.9237840

Boustani, N. M., \& Chedrawi, C. (2019). Innovation, New Public Management and Digital Era Government, Towards a Better Public Sector Performance Through ICT: The Case of the Lebanese Ministry of Environment. In Lecture Notes in Information Systems and Organisation. https://doi.org/10.1007/978-3-030-10737-6_12

Brill, J. (2016). Logic Model Guides Agencies in EVALUATING TRAINING Program Effectiveness. Training+Development, June.

Bunea-Bontas, C. A., \& Petre, M. C. (2011). Arguments for Introducing Accrual Based Accounting in the Public Sector. SSRN Electronic Journal. https://doi.org/10.2139/ssrn.1491663

David Wilkinson and Peter Birmingham. (2003). Using Research Instruments- A Guide For Researchers. In Igarss 2014. https://doi.org/10.1007/s13398-014-0173-7.2 
Deming, D. J., Goldin, C., Katz, L. F., \& Yuchtman, N. (2015). Can Online Learning Bend the Higher Education Cost Curve? American Economic Review, 105(5), 496-501. https://doi.org/10.1257/aer.p20151024

Departemen Keuangan Republik Indonesia dan Badan Perencanaan Pembangunan Nasional. (2009). Pedoman Penerapan Penganggaran Berbasis Kinerja (PBK).

Goldschmidt, K. (2020). The COVID-19 Pandemic: Technology use to Support the Wellbeing of Children. Journal of Pediatric Nursing. https://doi.org/10.1016/j.pedn.2020.04.013

Harun, H., An, Y., \& Kahar, A. (2013). Implementation and challenges of introducing NPM and accrual accounting in Indonesian local government. Public Money and Management, 33(5), 383-388. https://doi.org/10.1080/09540962.2013.817131

HOOD, C. (1991). A PUBLIC MANAGEMENT FOR ALL SEASONS? Public Administration. https://doi.org/10.1111/j.1467-9299.1991.tb00779.x

Iivari, N., Sharma, S., \& Ventä-Olkkonen, L. (2020). Digital transformation of everyday life How COVID-19 pandemic transformed the basic education of the young generation and why information management research should care? International Journal of Information Management. https://doi.org/10.1016/j.ijinfomgt.2020.102183

Indrawati, N. (2010). Penyusunan Anggaran dalam Era New Public Management: Implementasinya di Indonesia. Jurnal Riset Akuntansi Dan Bisnis, 10(2), 176-193.

Oktaviani, M. (2016). Analisis atas Target dan Struktur Biaya dalam Penentuan Bobot Biaya Output yang Bersifat Sulit Diestimasi (Studi Kasus: Ditjen Kekayaan Negara Kementerian Keuangan). Universitas Indonesia.

Radha, R., Mahalakshmi, K., Kumar, V. S., \& Saravanakumar, A. R. (2020). E-Learning during Lockdown of Covid-19 Pandemic: A Global Perspective. International Journal of Control and Automation.

Selim, H. M. (2007). Critical success factors for e-learning acceptance: Confirmatory factor models. Computers and Education, 49(2), 396-413. https://doi.org/10.1016/j.compedu.2005.09.004

Sun, P. C., Tsai, R. J., Finger, G., Chen, Y. Y., \& Yeh, D. (2008). What drives a successful eLearning? An empirical investigation of the critical factors influencing learner satisfaction. $\begin{array}{lll}\text { Computers and } \quad \text { Education, } & \text { 1183-1202. }\end{array}$ https://doi.org/10.1016/j.compedu.2006.11.007

Utomo, A. P. (2020). WHO Umumkan Virus Corona sebagai Pandemi Global. Kompas.Com. https://www.kompas.com/global/read/2020/03/12/001124570/who-umumkan-viruscorona-sebagai-pandemi-global?page $=$ all

Wicaksono, W. (2020). WHO Resmi Umumkan Virus Corona sebagai Pandemi. Liputan6.Com. https://www.liputan6.com/news/read/4199725/who-resmi-umumkan-virus-corona-sebagaipandemi?source $=$ search

Yin, R. K. (2015). Studi Kasus: Desain dan Metode (M. Djauzi Mudzakir, Penerjemah) (Edisi Revi). Rajawali Pers.

Yin, R. K. (2016). Qualitative Research from Start to Finish Second Edition. In THE GUILFORD PRESS. https://doi.org/10.1007/s13398-014-0173-7.2

Zhang, D., Zhao, J. L., Zhou, L., \& Nunamaker, J. F. (2004). Can e-learning replace classroom learning? Communications of the ACM, 47(5), 75-79. https://doi.org/10.1145/986213.986216 